\title{
La fotografía como fuente histórica en la construcción de las historias locales
}

Rosa del Valle Ferrer y Carolina del Valle Olivares UNSJ-FFHA

\section{Resumen}

Este artículo pretende dar a conocer la experiencia de trabajo obtenida en el marco de diversos proyectos de investigación relacionados al uso de las fuentes orales y audiovisuales en la construcción de la historia reciente.

El rescate de la memoria constituye el objetivo primordial del trabajo realizado a lo largo de estos años, en las cuales, el testimonio oral acompañado de imágenes fotográficas sustentaron un relato histórico cualitativamente significativo que nos permite abordar la realidad social y las relaciones de los actores sociales en el tiempo.

$\mathrm{Al}$ ser la fotografía una fuente de reciente incorporación en los estudios históricos, es que su uso planteó diversos interrogantes, tales como:

¿Las fuentes audiovisuales, específicamente las fotografías, constituyen fuentes importantes para la construcción del conocimiento histórico?; ¡cómo deben ser analizadas?; ¡constituyen verdaderos soportes/
Palabras clave:

metodología, fotografía, registro, oralidad, historia. 
disparadores de las memorias?; ¡cómo construir relatos históricos con fotografías?

Nuestra formación disciplinar nos resultaba insuficiente para abordar estas temáticas, por lo tanto se inició todo un proceso de formación teórica y metodológica que se plasmó en el diseño e implementación de un modelo de análisis de la fuente fotográfica, reflejado en un instrumento metodológico que reúne las variables de análisis requeridas. Surgió así la «Ficha Modelo de Registro Fotográfico» la cual será puesta a consideración en esta oportunidad.

El uso de las fuentes fotográficas en la historia provincial se suma a diversas iniciativas de otros ámbitos constituyendo verdaderos bancos de imágenes, que son empleados para la construcción de la historia a escala local.

\section{Abstract}

This article seeks to highlight the work experience obtained in the framework of several research projects related to the use of oral and visual sources in construction in recent history.

The rescue of memory is the primary objective of the work done over the years, in which the oral testimony accompanied by photographic images sustained a qualitatively significant historical narrative that allows us to tackle social realities and relations of social actors over time.

Photo Being a source of recent addition in historical studies, is that its use raised several questions, such as:

Audiovisual sources, specifically photographs, are important sources for the construction of historical knowledge?; How should they be analyzed?; Do they constitute an effective support / triggers memories? How to build historical stories with pictures?

Our disciplinary training was insufficient for us to address these issues, therefore a process of theoretical and methodological training which resulted in the

\section{Keywords:}

methodology, photography, register, orality, history. 
design and implementation of an analytical model of photographic source, reflected in a methodological tool that gathers started the variables of analysis required. Thus arose the "Data Model Photographic Record" which will be submitted for consideration at this time. The use of photographic sources in history adds to provincial initiatives in other areas constituting true image banks, which are used for the construction of history locally.

Esta investigación pretende dar a conocer la experiencia de trabajo obtenida en el marco de diversos proyectos relacionados al uso de las fuentes orales y audiovisuales en la construcción de la historia reciente.

Esta tarea nos ha ayudado a comprender que en el quehacer de la fotointerpretación histórica hemos advertido problemáticas desde el punto de vista técnico e interpretativo.

El abordaje de fotográficas como fuentes históricas ha recorrido un importante itinerario en nuestras investigaciones como investigadoras de la oralidad.

Desde hace décadas, el uso de la fotografía como fuente histórica ha sido entendido como un complemento enriquecedor para la reconstrucción de las historias locales. En este sentido, diversos proyectos de investigación en historia oral, de los cuales formamos parte, han abarcado una multiplicidad de aspectos de la vida de los sanjuaninos en el marco de la historia reciente. Algunos hitos importantes fueron:
- El terremoto de I944 en el sentir de los sanjuaninos.

- Las formas de entretenimiento infantil: juegos y juguetes

- Ritos de paso (nacimientos, bautismos, comuniones, casamientos, momentos de la muerte).

- Transportes y comercio en la primera mitad del siglo xx.

- Fotografía y género: mujeres fotógrafas y las mujeres en el mundo del trabajo.

En un comienzo, la inclusión de la fotografía pasó de ser un mero soporte ilustrativo a una verdadera fuente histórica. Este cambio de mirada en cuanto a las posibilidades de análisis de la fotografía demandó una preparación teórica metodológica buscada intencionalmente en el cruce de trabajos interdisciplinarios en el marco de las investigaciones.

Desde nuestra perspectiva de investigadores sociales, provenientes del campo de la historia y de la antropología, este 